\title{
The Role and Reason Why Armenians Were Selected as Iranian Businessmen During the Shah Abbas's Era
}

\author{
Zainullah KARIMI ${ }^{1}$
}

1: Samangan University, Education Faculty, Department of History, Samangan, Afghanistan.

\begin{abstract}
The main purpose of this paper is to examine the function of the Armenians merchant during the Safavid period. Shah Abbas turned to Armenian merchants to implement a silk monopoly policy. This approach also turned to Armenian personal and social experiences and characteristics. The abundance of silk production and its importance as export and strategic commodity, it has led to the adoption of its monopoly policy by Shah Abbas I. (1588-1629). (Falsafi, 77) Followed by the use of qualified Armenian merchants were implement this policy. Hence, it is a question of how the Armenian merchants played a role in the economy and politics of the Safavid. For a closer look at this role, after looking at the little silk collection bag, it has been tried to explain the reasons for the silk monopoly policy as well as the reasons for the use of Armenian businessmen as executors of this policy. Armenian merchants with their individual and group capabilities have been able to find new markets for Iranian silk in global markets. Accordingly, the study of the Armenian merchants shows that they not only affected Iran's foreign relations and foreign policy but also expanded foreign trade, increased imports of money and goods, the establishment of a balance in foreign trade and the economic situation the social business of the merchants also promoted silk work.
\end{abstract}

Keywords: Silk, Armenian Merchants, Foreign Trade, Monopoly Policy, Safavid.

\section{Introduction}

Before looking at the sources of Shah Abbas's acquisition of Armenians and their recruitment, a brief look at their biological background seems necessary for further understanding of this kind of commerce.

The reason Armenian merchants were chosen by Shah Abbas I. for international trade was lack of efficiency and some barriers for Iranian businessmen in global markets. The Armenians were ethnic businessmen who had acquired the necessary experience in this field. Many of them came across Europe and became aware of the dangers of commerce in distant countries. The sources indicate that the Armenians had achieved wealth through the trade-in their mainland. Even a large number of them have been engaged in silk trade in their original lands.
Armenians settled before their migration in their original and historic life, in the northern and northwestern border regions of Iran, Armenia, Georgia, Shirvan, Nakhichevan and Jolfa. They formed the largest population of Iranian Christians and belonged to the Church of Gray Goury (Lockhard.86 page .The compulsory forced migration of Armenians from their main lands was the wars and long conflicts between the two Ottoman Empires and Iran. From the report of Pietro Della Valle can found: The Shah has ordered to move these people from different parts of the country to Isfahan so that they are not close to the borders of the Turks, and the risk of their loss and captivity being abandoned by the Turks. In general, the Shah hid as much as possible the boundaries of the land and transferred them to the center and provided them with other lands to ensure their 
survival in the country and the city of Isfahan bigger and richer and more beautiful. (Della Valle.36). For these reasons, Shah Abbas I during the years 1017 to 1013 displaced thousands of Armenians from the border areas to the interior of Iran and settled in cities such as Tabriz, Qazvin, Gilan, Anzali, Darband, and Kashan. He resettled the Armenians of the Jolfa of Aras, about three thousand households, on the other side of the Zayandeh River in Isfahan, and in places such as Abbas Abad, Shams Abad, and in particular in a place that later became known as the Jolfa. (Du Mans. 182). In general, there are no precise figures from the number of Armenian immigrants. But Tavernier has written 27,000 populations of households and Jean Chardin has written around 30,000 households them. (Tavernier 56, Chardin 25-26). It seems that these statistics, apart from the three thousand households that have been transferred from Jolafa Aras to Jolfa of Isfahan. Because it drew the 30,000 families that Chardin mentioned was destined only to the regions of Armenia and Georgia to Mazandaran, on the other hand, the population of the Armenians of Jolfa of Isfahan, due to the particular interest of the Shah and the better facilities, had risen. As in the late Safavids, the Jolfa population ran between 30,000 and 35,000 populations, the total population has been estimated at 170,000 throughout Iran. (Lockhart 86).

\section{Materials and Methods}

Since this study is intended as qualitative research, the primary material used is the information obtained from the literature and the observations of the researcher. In this context, journal articles, books, and the internet have been widely used. The study has been organized taking into consideration the main objectives of the study. The role and reason why Armenians were selected as Iranian businessmen during Shah Abbas's Era are explained in the introduction of the study. Subsequently, various economics, international trade, and international role were explained in the research results and discussion section of the study. The study ends up with a series of measurements to be taken to accelerate history research in the university.

\section{Finding And Discussion}

As mentioned, Shah Abbas began to implement the monopoly policy for Armenian merchants and, of course, he had various reasons for implementing the monopoly policy, the most important of them were:

1.The lack of efficiency and some barriers for Iranian businessmen (non-Armenians) in international trade. To enforce monopoly policy, it required the competent and experienced merchants to find new markets in distant countries and to supply Iranian silk in those markets. Shah Abbas found that trade in various territories of the world, especially in the remote European Christian countries, required certain abilities and conditions that Iranian businessmen would not take for granted . In this regard, two specific examples can be mentioned. One is that he, in the year 1017, sent a Qizilbash named Dengizbeg Romulo with a Portuguese named Antonio de Gouveia as Ambassador to King Philip of Spain to unite against the Ottoman Turks and develop trade relations. In addition to the gifts, King 50 silk balms are also accompanied by the ambassador for marketing and sales in the country. But the ambassador, instead of selling silk and returning it to the treasury, offered all this to the King of Spain owing to his Portuguese condemnation. Besides, he committed other mistakes that he was sentenced to death upon his arrival in Iran (Roger Mervyn Savory 100). However, the king once again sent an Isfahan born businessman with a lot of silk to trade in Venice. But he did not give a better test than the ambassador, and after selling the silk, he paid tribute to his money. But there, the government of Venice seized the remains of the merchant's property and brought the issue to the attention of the king of Iran. Subsequently, Shah Abbas, under the command of the year 1018, reciprocated Khaja Safer Armenian with another person, commissioned and received the remaining property of kingship (the correspondence of Shah Abbas I.7). On the other hand, Muslim merchants could not perform Religious ceremonies in non-Islamic countries; it would have problems and obstacles. They had little interest in commerce with non-Muslim nations in distant lands. Therefore, Shah Abbas turned to more Armenian merchants who were more experienced. (Chardin 367) 
2. The individual abilities and economic experience of Armenians. Apart from the barriers mentioned in the case of Iranian businessmen, the use of Armenians in foreign trade has two other major causes: One was their learning and experience, and other personal, emotional and social characteristics. Before being employed by the Shah Abbas, the Armenians were ethnic businessmen who had acquired the necessary experience in this field. Many of them came across Europe and became aware of the dangers of commerce in distant countries. The sources indicate that the Armenians had achieved wealth through the trade-in their mainland. Even a large number of them have been engaged in silk trade in their original lands. Likewise, when Tabriz was the capital of the Safavids, a large number of Armenians were also involved in trade, from different parts; they exported Silk and other commodities into or other parts of the country (Venetian Travelers in Iran. 13-12). During the reign of Shah Abbas. I (Decree 984-930), Armenians competed with Turks, Venetians and English merchants, and they were more comfortable with knowledge and facilities because of their indigenous nature. They also had a better understanding of the ways, cities, and business conditions of neighborhoods that foreign businessmen were deprived of. (See: Ferrier, 434435). Along with these experiences, their personal and hard work characteristics made them more deserving of commerce in distant lands. The sources show that the Armenians were hard-working and tireless long-distance travel. Nevertheless, one of the most important features that they privileged in their foreign trade to Iranian merchants was their familiarity with European languages. For this reason, they could better communicate with Europeans and because they were Christians. They could have been better able to market Christian Europeans. Tavernier, a world-class merchant, has seen Armenian businessmen as contented, savvy and hard-working people (Tavernier, 406). These features are also confirmed in another report: "from the house with a few eggs and some wine, and they go to Isfahan to the harbor ... They are in the trade like armed merchant ships, not buying, or spending. With such a beginning, they sometimes achieve great success for themselves and their lords" (Fryer, 249).

Such experiences and abilities that prioritized the Armenians in the view of Shah Abbas for foreign silk business. Hence, he chose those of them who were more deserving and gave each one as much talent as he could to sell them in other countries. After returning to the country, they paid the price of silk at the rate that the Shah had set and benefited from the cost of their travel and wages (Tavernier, 405-406).

\section{The international role of Armenian merchants}

Following the implementation of the monopoly policy, there were some restrictions on the free sale of silk. But it has increased and expanded its foreign trade. As noted, the domestic trade of Iran was mostly in the hands of Iranian and non-Iranian elements, such as Jews, Indians, and others. But foreign trade was more in the hands of the Armenians, who were the king's agents and rulers of the country. They made the greatest contribution to the trade of Iranian silk with other countries and important economic centers of the world. Therefore, to better understand their roles, they should consider the range of foreign trade areas and activities carried out in those areas. These areas can be geographically divided into two parts:

3.Eastern countries: The markets in this area included neighboring countries, sub-continent of India and other Asian territories. As long as Iran's trade with these countries was carried out in the eastern and southeast directions of Iran, Armenian merchants were based in important transit trade centers such as Kabul, Kandahar, and Herat. Armenian trade with India, both in their efforts and with the help of Dutch and English companies. In this regard, Khaja Nazar was one of the elders of the Armenian community of Jolfa, in Esfahan, in 1620, asked the East Indian Company to cooperate in transporting merchants and their businesses to India and Surat (Soltaniyan, 65), as well as many Armenians in the port Abbas has been deployed and has extensive business networks across the country and India and China. The merchants were not as powerful as Khaja Minas. He was a resident of Isfahan and one of the major merchants in Surat, who was engaged in large-scale commercial 
activities in the 1660s. He had a lot of cash and, while hiring British ships, he also had a number of merchant ships. (Soltaniyan, 66-65)

Among the eastern countries, Iran's trade with India was much wider, and besides silk, it included various items. The most important exports to Iran were silk and silk goods. One of the best types of silk produced in Iran, known as "Milani", was produced in Khorasan, and most of it was exported to India (Floor, 37). Apart from raw silk, its derivatives, such as all sorts of cloth, brocade, cloth, carpet, foulard, and so on. Of course, against this export to the Indian subcontinent, various commodities such as spices, skin, Indian steel, precious metals, coins, etc., also entered in Iran. According to Rafael Dahman, the head of these imports was Indian linen fabrics, which accounted for a huge volume of imports into Iran. Part of these fabrics, along with other goods, was again in the foreign trade chain of Iran and was exported to other countries (Du Mans, 180) beyond India, Iran's trade in the east to the furthest parts of Asia, such as Ceylon, Tonkin, Java, The Philippines, and so on.

Ottomans were another country where Armenians were keen on doing business. The trade relations between Iran and the Ottoman Empire were more or less settled in times of war and insecurity. The Iranian businessmen insisted on continuing the trade with that country through traditional ways contrary to Shah Abbas I's desire to return trade from the Ottoman route to the sea. Because not only the Ottoman cities were important centers for trading with Europeans and Venetians, but also the necessity of requiring the knitting works of that country to the silk of Iran. Izmir was one of the important centers of the Ottoman commerce Where Armenian merchants sold Iran's silk to Europeans preferring to French because they were paying the price of silk in cash (Tavernier 94-93). Apart from Izmir, Erzurum, Aleppo, and the Eastern Mediterranean ports, they were also centers of international trade and Armenians through the centers, trading with the Ottomans and European traders.

Western countries: The sources indicate that the Armenian business has become wider in Western countries and their activities in this area. Russia was part of this sector, where part of the silk trade traded there. The Russian government was willing to send all the Caspian coastal silk to the country by the seaway, so European customers would have to buy from Russian merchants. In 1627, Russian Tsar "Michael Romanov", by his ambassador, asked Shah Abbas I to conclude a contract to send Caspian Sea silk products to that country. In his response, Shah Abbas sent 50 silk balms with his ambassador to Russia, but delayed the agreement of the contract (Falsafi, 77). Thereafter, the two countries did business together. Since 1667, Armenian businessmen have had a better chance of trading in the country. Because, after the Russian Tsar «Alexei Mikhailovich» had been attacking Swedes, Dutch, French, and Russian businessmen had entered the eastern commercial markets directly from Russia. This event allowed Armenian merchants to travel through Astrakhan on Russian and sell Iranian goods, especially silk, to European buyers. According to Anthony Jenkinson, Iran silk and silk merchandise arrived in Astrakhan, and Russian Tsar encouraged the Armenians to trade in that city. (Jenkinson, 58-9). The exclusive position of Armenian merchants in Russian territory was tightened up after 1688 when they signed a commercial agreement with Sweden to export goods from Russia via Scandinavia (Gregorian, 670). Meanwhile, silk merchants of Iran have been closely cooperating with Italian traders, especially Venice. They transferred Iran's silk from the roads of Izmir and Aleppo to the Mediterranean Sea, then to Venice and Liguria, or its other trading centers on the Mediterranean coast and the Crimean Peninsula. They also sent it to the great European countries of the time, such as Spain, Poland, Hungary, France, Netherlands, and the United Kingdom. In contrast to the issuance of silk, Armenian merchants from Venice and other areas, cash and precious metals such as Piaster, Skokie Gold and Sakin Aside from money, goods like mirrors, glasses, scissors, amber, corals, colored glass for the manufacture of windows and other Venetian goods were also imported. (Du Mans, 181). Apart from cooperative partnerships, Armenian businessmen established their special dealerships in the cities of Amsterdam, Venice, and Livorno. A group of well-known 
Armenian businessmen in Amsterdam managed to maintain their trading position throughout the seventeenth century and a large part of the 18th century. One of the most active Armenian businessmen, whose efforts to expand Iran's foreign trade have not been much addressed, was Philip Dazaggali. He was born in Jolfa of Isfahan and was the son of a goldsmith. The documents reveal that he had undertaken many political and economic measures to expand Iran's foreign trade. In 1669, intending to develop business relations, he and other Armenian businessmen entered in Paris, where he married to sister in law of Tavernier, a well-known businessman, to advance his goals. (114-113, 134, Gulbenkian) Dazaggali followed by travels to the Netherlands, Germany, Sweden, Poland, Moscow, and Turkey. But his most important role in these trips was to provide the necessary grounds for the establishment of Armenian merchants in the Corrland in 1696. According to available documents, he succeeded in signing a contract with the Duke of Corrland this year, whereby he received privileges for Armenian merchants. Among these privileges were residence permits, purchase, and sale of real estate and business activities. As mentioned, the Armenians were more inclined to export silk from Asia Minor and Ottoman territory to Europe, which was more straightforward and closer. At the same time, they exported silks and other Iranian goods by seaway with the ships they had and with the charter of the British and Dutch

\section{Conclusion}

In this research, the reason for choosing Armenians as an Iranian businessman and the role of Armenian merchants in their export and sale was the cycle of the Silk Economy. They were more likely to be familiar with European languages as well as to be better off among their Christian counterparts, there were also individual, collective, and special spirits that were able to introduce Iran's silk to various realms around the world, some of which, such as the Cortland area, were identified and introduced. At the same time, not all of these areas are well known and require more research in this regard. Thus, with the help of the experienced Armenian businessmen and the adoption of a monopoly policy, Silk exports to different countries increased, and foreign trade also companies to the east and west of the world. In the same vein, Khaja Panos Kalantar, an Armenian businessman based in London, signed an agreement with the British East Indian Company in London in 1688 to represent the Armenians of Isfahan to carry Armenian merchandise through the sea to Europe. (Gulbenkian, 138). Thus, the Armenians played a positive role in the foreign trade of silk and trade with the countries of the east and west of the world. With their efforts, Iran's foreign trade reached a proper balance with the West in the course of this period, and its deficit with the East, in particular, India was greatly offset. By issuing silks and establishing a trade balance, the country's income also increased. Iran has estimated the proceeds from the sale of silk, which, in the best of terms, is between two million to two million and five hundred thousand lire (six hundred to seven hundred and fifty thousand tomans). Aside from the goods, it imported a lot of expensive metals and coins, according to Chardin, without Armenians, the monetary circulation of the country was almost impossible. This indicates the economic importance of silk, and also among the reasons why Shah Abbas got it to his monopoly and used Armenians there. Another economic result of silk trade has been the establishment and strengthening of Iran's relations with European countries and the conclusion of economic and political agreements with them. Also, the supply of silk to world markets has caused Iran's most famous reputation in the world to date. flourished dramatically. As a result, with the arrival of money and expensive

metals, equilibrium in Iran's foreign trade, which suffered a deficit, came into being, and the country achieved monetary and financial stability. Besides, the socioeconomic status of silk merchants has also been promoted in the community.

Nevertheless, the golden era of the silk trade, as well as the privileged position of its Armenian merchants, from the era of the Shah Suleiman, As a result of bad politics, the rulers and social-political bottlenecks began to decline and ended in the era of Afghan rule. Along with internal degeneration, hard rivals were also found in the global markets for silk in Iran, which in total had devastating consequences for the silk economy of Iran. 


\section{References}

[1] Chardin, J.-B. (1350). Chardin's (4 ed.). (A. Mohammad, Trans.) Tehran: Amir Kabir.

[2] Della Valle, P. (1348). The Travels. (S. Shafa, Trans.) Tehran: Bangah.

[3] Du Mans, P. R. (1890). Estat de la Perse en 1660. Paris: publie par Ch.Schefer Ernest Leroux.

[4] Falsafi, N. (1353). Tujarat Abrishum Dar Zaman Shah Abbas I. Mujallayi Wahid, 1,2.

[5] Floor, W. (1356). The first Persian Ambassador to Holland. (H. A. Darush Majlisi, Trans.) Tehran: Tahuri.

[6] Ferrier, R. (1986). Trade from The Mid-14th century to The End of The Safavid period (Vol. 6). London: Cambridge History of Iran.

[7] BIBLIOGRAPHY l 1033 Fryer, J. (1912). A New Account of East India and Persia (Vol. 2). London: Hakluyt Society.

[8] Gregorian, Vartan, «Minorities of Isfahan (Armenian community of Isfahan 15871722)», Iranian Studies, 1974, vol. 7.

[9] Gulbenkian, R. (1352). Dazaggali ve Istiqrar Tujara Iran Dar Curland. Mujallyi Barrasi Hayi Tarikhi , 2.

[10] Jenkinson, Anthony, Early Voyages and Travels to Russia and Persia, New York, Burt Franklin, First Series, 1886, No. 79.

[11] Lawrence, L. (1958). The Fall of the Safavi Dynasty and the Afghan Occupation of Persia. (M. G. Emad, Trans.) Tehran: Marvarid.

[12] Soltaniyan, A. T. (1388, 12 10). Rawabit Bazar Ganiz Iran ve Hind dar Dourayi Safaviya. Fasil Namayi Rawabit Tarikh Khariji, p. 66.

[13] Tavernier, J. B. (1336). Tavernier's Travel in India (2 ed.). (N. Abu Turab, Trans.) Tehran: Sanayi.

[14] BIBLIOGRAPHY $\backslash 11033$ Venetian Travels for Persia (2 ed.). (1381). (M. Chehr, Trans.) Tehran: Khuwarazmi. 